\title{
PRODUCTION OF COPPER NANOPARTICLES ON GLASS SUBSTRATE FROM E-WASTE
}

\author{
Khalil, M. M. H. ${ }^{(1)}$; Taha M. A. Razek $^{(2)}$; Rabah, M. A. ${ }^{(3)}$ \\ and Eldawy, Sh. A. \\ 1) Chemistry Department, Faculty of Science, Ain Shams University \\ 2) Environmental basic science, Institute of Environmental Studies and \\ Research, Ain Shams University 3) Chemical and Electrochemical Treatment \\ of Minerals, Mineral Treatment Division, Central Metallurgical Research and \\ Development Institute.
}

\begin{abstract}
E-waste is considered hazardous waste because it contains some heavy metals. Extraction and utilization of these metals is highly appreciated. Spent e-waste was used as an input material to prepare copper nanoparticles using up to $33 \%$ ammonia solution. The resulting solution was acidified by sulfuric acid to yield copper (II) sulfate. The substrate material was made of crushed glass coated with carbon film. The substrate particles were dipped in copper (II) sulfate solution. The reducing material was hydrazine hydrate and/or ascorbic acid. Results showed that ammonia has been proved to dissolve copper at $20^{\circ} \mathrm{C}$ up to $90^{\circ} \mathrm{C}$. The extent of dissolution depends on concentration, temperature and time. Ascorbic acid to be more effective as compared to hydrazine hydrate to produce copper ions to metallic form. Particle size measurement showed that the copper particle size range from $26.22 \mathrm{~nm}$ to $400.9 \mathrm{~nm}$ with ascorbic acid, from $35.12 \mathrm{~nm}$ to $669.7 \mathrm{~nm}$ with hydrazine hydrate and from $35.12 \mathrm{~nm}$ to $658.4 \mathrm{~nm}$ with mixture of them. Results were explored with the help of FESEM. Results have been found friendly, simple and economic process.

Key words: E-waste, printed circuit boards (PCB), carbon coated glass (CCG).
\end{abstract}


J. Environ. Sci.

Institute of Environmental Studies and Research - Ain Shams University

\section{INTRODUCTION}

The demand of electrical and electronic equipment (EEE) has increased widely with the progressing in technology. The innovations on the electrical and electronic technologies further shortened the life, and thus supported the generation of waste from electrical and electronic equipment (WEEE) or electronic waste (e-waste).

European Parliament (2003) expected that the production of e-waste in Europe will increase by $45 \%$ between 1995 and 2020. Therefore, to minimize the environmental impact and promote the efficient utilization of wasted resources, a three pillars strategy of waste prevention, recycling and reuse has been suggested.

Robinson (2009) reported that 20 to 25 million tons per year of e-waste are being generated all over the world with major rate in Europe, USA and Australia.

Afroz et al. (2013) showed that WEEE is recently the fastest growing solid waste at an annual growth rate of 3-5\%. Marques et al. (2013) reported that concerns have grown regarding the value and hazards presented by WEEE of particular interests are the re-utilization and recovery of printed circuit boards (PCBs) which are the main parts of electronic devices and constitute around 3 wt. \% of WEEE. On the other side, Noon et al. (2011) explained that waste PCBs may lead to tragic health, safety and environmental issues as there are several hazardous materials contained in PCBs, such as lead (in solder), antimony (in solder), beryllium(in 
connectors), cadmium (in contacts and switches), and brominated flame retardants (in plastics).

Goosey and Kellner, (2003) and Flandinet et al. (2012) showed that PCBs also contain a substantial quantity of valuable metals. It is known that the typical PCBs are made up of non-metal (plastic, resins, glass fibers, etc.) more than $70 \%$, copper, about $16 \%$, solder (mostly tin and lead), $4 \%$, iron and ferrite $3 \%$, nickel, $2 \%$, silver $0.05 \%$, gold $0.03 \%$, and palladium $0.01 \%$ in which precious metals take up over $70 \%$ of the recovery value, while copper about $20 \%$.

Hagelüken (2006) classified metals in e-waste into precious metals PMs ( $\mathrm{Au}$ and $\mathrm{Ag}$ ), platinum group metals PGMs (Pd, Pt, Rh, Ir and $\mathrm{Ru}$ ), base metals BMs ( $\mathrm{Cu}, \mathrm{Al}, \mathrm{Ni}, \mathrm{Sn}, \mathrm{Zn}$ and Fe), metals of concern MCs ( $\mathrm{Hg}, \mathrm{Be}, \mathrm{In}$, $\mathrm{Pb}, \mathrm{Cd}, \mathrm{As}$ and $\mathrm{Sb}$ ) and scarce elements SEs (Te, Ga, Se, Ta and $\mathrm{Ge})$.

Cui and Zhang (2008) and Yang et al. (2013) reported that recovering metal values from waste PCBs can be performed by various processes such as physical techniques, pyrometallurgical processes, pyrolysi and hydrometallurgical processes. However, these processes still share some limits, such as complicated flow-sheet, harsh operating conditions and applicability of just one or two specified materials of all PCB compositions.

Copper is a reddish colored, takes on a bright metallic lusterous, and is malleable, ductile, and a good conductor of heat and electricity (second only to silver in electrical conductivity). The electrical industry is one of the greatest users of copper. 
The most important compounds are the oxide and the sulfate, blue vitriol; the latter has wide use as an agricultural poison and as an algaecide in water purification. Copper compounds such as Fehling's solution are widely used in analytical chemistry in tests for sugar. F.p. $1084.62{ }^{\circ} \mathrm{C}$; b.p. $2562^{\circ} \mathrm{C}$; sp. Gr. $8.96\left(20^{\circ} \mathrm{C}\right)$.

In the recent years, as copper has high conductivity and low cost, making its nanoparticles are promising material. Mustafa and İlkay (2010) reported that copper nanoparticles have potential for use in nanomaterials, thermal conducting applications, catalysts, lubrication, and nanofluids. Moreover, Sinha et al. (2002) showed that substitution of noble metal powders such as gold or silver with copper powder is a current trend in the electronics industry.

Oh et al. (2003) and Yang et al. (2011) reported that over 96\% of copper recovery from PCB by sulfuric acid solution with hydrogen peroxide as an oxidant at room temperature indicating that leaching of PCB by sulfuric acid in the presence of hydrogen peroxide is a suitable option for recovery of copper as a first leaching stage.

Cheng et al. (2006) found that copper nanoparticles have synthesized in the surrounding atmospheric temperature and pressure necessarily have surface oxide layers because the copper oxide phases are thermodynamically more stable thanpure copper. They also added that copper particles are strictly aggregated without suitable protection. The problems of aggregation and oxidation can be avoided by the use of various protecting agents, such as polymers and organic ligands. 
Thi et al. (2011) proposed that a simple and rapid approach to pure copper nanoparticle preparation by ascorbic acid, which is an antioxidant with no gas protection. Ascorbic acid is necessary to avoid the oxidation of copper nanoparticles during the synthesis process and in storage. The antioxidant properties of ascorbic acid is due to its ability to recapture free radicals and reactive oxygen molecules accompanying the donation of electrons to give the semi-dehydroascorbate radical and dehydroascorbic acid.

Zhang, et al. (2010) synthesized copper nanoparticles using potassium borohydride as reducing agent. The effects of reactant ratio, concentration of $\mathrm{CuSO}_{4}$, temperature, and dispersant on the size of product and conversion rate were studied. They added that the average particles size of copper powders with spherical shape gained is about $100 \mathrm{~nm}$.

The chemical structures of hydrazine hydrate and ascorbic acid are as represented in Fig. (1 a \& b). Mustafa and İlkay (2010) showed the reaction between $\mathrm{Cu}^{2+}$ ions with ascorbic acid by equation (1) while Chen and Lim (2002) explained the reaction with hydrazine by equation (2).

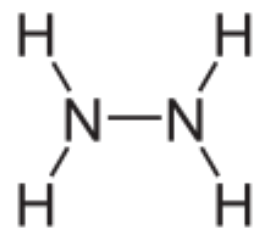

(a)<smiles>O=C1O[C@H]([C@@H](O)CO)C(O)=C1O</smiles>

(b)

Fig (1:a\&b): Chemical structure of (a) hydrazine hydrate and (b) ascorbic acid. 


$$
\begin{array}{ll}
2 \mathrm{Cu}^{2+}+\mathrm{N}_{2} \mathrm{H}_{4} & 2 \mathrm{C} \mathrm{u} \gg \mathrm{N}_{2}+\underset{\Downarrow}{4 \mathrm{H}^{+}} \ldots \ldots \\
\mathrm{Cu}^{2+}+\mathrm{C}_{6} \mathrm{H}_{8} \mathrm{O}_{6} \quad \mathrm{C} \ddot{\mathrm{u}} \rightarrow \mathrm{C}_{6} \mathrm{H}_{6} \mathrm{O}_{6}+2 \mathrm{H}^{+} \ldots \ldots
\end{array}
$$

In this study, some trials were carried out to explain a relationship between the effect of concentration of copper salt solution as well as the grade of the substrate to which copper nanoparticles are deposited and the size and shape of the nanoparticles formed. This could be shown by preparation of copper nanoparticles by addition of hydrazine hydrate ascorbic acid and mixture of them to copper (II) sulfate on carbon coated glass (CCG) of different grades.

\section{MATERIALS AND METHODS}

Materials: Fourteen shredded PCBs of different brands without processors, jars, heating mantle, drier, oven, and glass wares .

Chemicals: Ammonia solution and sulfuric acid (products of Labort fine chem. PVT. LTD and El-Nasr company for Pharmaceuticals and Chemicals). Sodium carbonate, nitric acid, methyl orange indicator, hydrazine hydrate commercial product and ascorbic acid iron II sulfide, hydrochloric acid and copper (II) sulfate were of analytical grade and used without purification.

Collecting, cleaning and measuring weights of the PCBs: The PCBs were collected from spoiled computer stores, cleaned by washing with water then dry air, numerated and shredded. The weight of each sample is determined before and after shredding. 
Dissolution in ammonia: The samples have taken numbers from 1 to 14 . Specified weights from these samples were determined as shown in Table (1) and another weights of the first five samples were specified and these samples have been designated by $1 \mathrm{~A}-5 \mathrm{~A}$. By this there will be three solutions, the first one obtained by dissolving each of the fourteen samples in ammonia solution at room temperature with decanting and collecting solution produced 8 times. The second solution from samples $1 \mathrm{~A}-5 \mathrm{~A}$ dissolved in ammonia at $50{ }^{\circ} \mathrm{C}$ for repetition of separation of residue from the solution 5 times and the third solution at $90{ }^{\circ} \mathrm{C}$ for only once. The weights lost were shown in Tables (2 and (3). Three solutions obtained will be indicated as group one resulted from the fourteen samples, group two for solutions collected at $50{ }^{\circ} \mathrm{C}$ and group three from those collected at $90^{\circ} \mathrm{C}$.

Samples of group one were dissolved in $50 \mathrm{ml}$ ammonia solution at room temperature. After 3 days the solution was decanted to separate the residues which were washed by distilled water then dried at $90^{\circ} \mathrm{C}$. After drying $25 \mathrm{ml}$ of $25 \%$ ammonia solution were added to the residues for 6 days and the previous steps were repeated. After repeating the process for 8 times, the solutions were collected to be heated for recovering ammonia.

By applying the steps in group one by dissolving samples of group two and three in ammonia solution. The samples were heated at $50^{\circ} \mathrm{C}$ and then at $90{ }^{\circ} \mathrm{C}$. The solutions produced at these two degrees have been collected separately. The process was repeated six times.

Recovery of ammonia: Solutions of samples 1 - $5 \mathrm{~A}$ which at $50{ }^{\circ} \mathrm{C}$ and that at $90^{\circ} \mathrm{C}$ are heated separately till dryness. 
The solution collected from each group was heated using the mantle till dryness. Ammonia gas was collected and dissolved in distilled water then titrated with sulfuric acid of molarity $\left(\mathrm{M}_{\mathrm{a}}\right) 0.2 \mathrm{M}$ (standardized by sodium carbonate) and the volume $\left(\mathrm{V}_{\mathrm{a}}\right)$ of the acid needed to neutralize $10 \mathrm{ml}$ which is the volume $\left(\mathrm{V}_{\mathrm{b}}\right)$ of ammonia is $71 \mathrm{ml}$. The molarity $(\mathrm{Mb})$ of ammonia has been calculated to be $2.8 \mathrm{M}$ according to the following equation and the mathematical rule, where $n_{a}$ and $n_{b}$ are the numbers of moles of sulfuric acid and ammonia respectively.

$$
\begin{gathered}
\mathrm{H}_{2} \mathrm{SO}_{4}+2 \mathrm{NH}_{4}(\mathrm{OH})-\left(\mathrm{NH}_{4}\right)_{2} \mathrm{SO}_{4}+\mathrm{H}_{2} \mathrm{O} \ldots \ldots \\
\frac{\mathrm{M}_{\mathrm{a}} \mathrm{V}_{\mathrm{a}}}{\mathrm{n}_{\mathrm{a}}}=\frac{\mathrm{M}_{\mathrm{b}} \mathrm{V}_{\mathrm{b}}}{\mathrm{n}_{\mathrm{b}}}
\end{gathered}
$$

Dissolving in nitric acid: $50 \mathrm{ml}$ of nitric acid were separately added to the residues remained from three groups. Group one was sparingly soluble, group two was slightly soluble while group three was completely soluble.

Formation of copper sulfide and determination of copper: Distilled water was added to the solution of group three to complete it $100 \mathrm{ml}$, then $25 \mathrm{ml}$ has been taken to be reacted with hydrogen sulfide gas (synthesized from reaction of iron II sulfide with hydrochloric acid) which was passed through the solution producing black precipitate of copper sulfide $(\mathrm{CuS})$. The precipitate was dried after filtration at $50{ }^{\circ} \mathrm{C}$.

Synthesis of copper nanoparticles using hydrazine hydrate: $1 \mathrm{M}, 0.1 \mathrm{M}$ and $0.01 \mathrm{M}$ solution of copper sulfate were prepared by adding $20 \mathrm{ml}$ of distilled water to $4.99 \mathrm{~g}, 0.499 \mathrm{~g}$ and $0.0499 \mathrm{~g}$ of copper sulfate respectively. Hydrazine hydrate was added to each concentration followed by taking 
samples to detect the copper nanoparticles by field emission scanning electron microscope (FESEM). After filtration the precipitate of each was weighed.

Preparation of copper nanoparticles on carbon coated glass (CCG): Another technique was followed using three grades of crushed glass; grade 1 is less than $0.9 \mathrm{~mm}$, grade 2 is more than $0.9 \mathrm{~mm}$ but less than $2 \mathrm{~mm}$ and grade 3 is more than $2 \mathrm{~mm}$. The crushed glass was coated by carbon which was prepared by boiled saturated sugar solution. For each grade saturated solution of copper sulfate was added several times followed by decanting the excess solution to the original one then drying the $\mathrm{CCG}$ at $50-70{ }^{\circ} \mathrm{C}$ until its surface was coated by blue copper sulfate. Hydrazine hydrate and $1 \mathrm{M}$ ascorbic acid have been added to the grades. CCG grades have been divided into three groups weight of each is 3 grams. Hydrazine hydrate, ascorbic acid and mixture of them 1:1 in ratio were added individually to each grade. By preparing slides for detection the size of the nanoparticles obtained in each case using FESEM . The CCG groups are filtrated and the residues were dried at $50^{\circ} \mathrm{C}$ and weighed.

\section{RESULTS AND DISCUSSION}

Number of addition of ammonia is greater for samples 1-14 than that for group two while for group three is the smallest. The percentage of the lost weight is varied from one PCB to another depending on the components ratio in each and the temperature at which dissolution was taken place. The temperature factor is a firmly effective factor but a black residue is formed in group two and three not in group one. The residue was dissolved in distilled 
water. Temperature has increased the rate of dissolution. While in case of group one number of addition of ammonia has yielded high percentage of soluble copper.The weights of samples of groups one, two and three are shown in Tables (1), (2) and (3).

Table (1): Percentage of PCBs material soluble in ammonia at room Temperature.

\begin{tabular}{|c|c|c|c|c|}
\hline No. & Initial wt. $^{\mathbf{1}}$ & Final Wt. $^{\mathbf{}}$ & Loss of wt. $^{\mathbf{3}}$ & Percentage (\%) $^{\mathbf{*}}$ \\
\hline \hline 1 & 5.27 & 3.93 & 1.34 & 25.42 \\
\hline 2 & 5.13 & 3.85 & 1.28 & 24.95 \\
\hline 3 & 5.15 & 4.17 & 0.98 & 19.02 \\
\hline 4 & 5.19 & 4.41 & 0.78 & 15.02 \\
\hline 5 & 5.21 & 4.15 & 1.06 & 20.345 \\
\hline 6 & 5.30 & 4.44 & 0.86 & 16.22 \\
\hline 7 & 5.30 & 4.20 & 1.1 & 20.75 \\
\hline 8 & 5.52 & 4.66 & 0.86 & 15.57 \\
\hline 9 & 5.15 & 4.21 & 0.94 & 18.25 \\
\hline 10 & 5.54 & 4.73 & 0.81 & 14.62 \\
\hline 11 & 5.43 & 4.24 & 1.19 & 21.91 \\
\hline 12 & 5.49 & 4.55 & 0.94 & 17.12 \\
\hline 13 & 5.27 & 4.42 & 0.85 & 16.12 \\
\hline 14 & 5.22 & 4.52 & 0.7 & 13.40 \\
\hline
\end{tabular}

Table (2):Percentage of PCBs material soluble in ammonia at 50oC

\begin{tabular}{|c|c|c|c|c|}
\hline No. & Initial wt.1 & Final Wt. (50oC)2 & Loss of wt.3 & Percentage (\%) \\
\hline \hline 1A & 5.17 & 4.65 & 0.52 & 10.05 \\
\hline 2A & 5.31 & 4.73 & 0.58 & 10.92 \\
\hline 3A & 5.23 & 4.43 & 0.8 & 15.29 \\
\hline 4A & 5.15 & 4.50 & 0.65 & 12.62 \\
\hline 5A & 5.28 & 4.55 & 0.73 & 13.82 \\
\hline
\end{tabular}


Khalil, et al

Table (3): Percentage of PCBs material soluble in ammonia at $90^{\circ} \mathrm{C}$.

\begin{tabular}{|l|l|l|l|l||}
\hline No. & Initial wt. $^{1}$ & Final wt. $^{2}$ & Loss of wt. $^{3}$ & Percentage (\%) \\
\hline 1A & 4.65 & 4.26 & 0.39 & 8.38 \\
\hline 2A & 4.73 & 4.15 & 0.58 & 12.26 \\
\hline 3A & 4.43 & 4.12 & 0.31 & 6.99 \\
\hline 4A & 4.50 & 4.42 & 0.91 & 1.77 \\
\hline 5A & 4.55 & 4.43 & 0.12 & 2.63 \\
\hline
\end{tabular}

For Tables (1), (2) and (3):

1. Weight of shredded PCBs before dissolution in ammonia.

2. Weight of shredded PCBs after dissolution in ammonia.

3. Weight of soluble materials in ammonia

Copper percentage in group three: The choice of group three to determine the percentage of copper is due to the complete dissolution of the residue. The weight of copper sulfide in $100 \mathrm{ml}$ is $0.64 \mathrm{~g}$. By knowing the molar mass of copper sulfide which is $95.5 \mathrm{~g}$, so, the weight of copper in the precipitate is $0.425 \mathrm{~g}$. the total weight of samples of group two before dissolution is $26.14 \mathrm{~g}$ while that after drying is $21.38 \mathrm{~g}$, resulting in the weight of copper dissolved in ammonia solution is $4.76 \mathrm{~g}$ with percentage $8.928 \%$. This percentage is nearly equal that produced by XRF which shows that the concentration of copper as copper oxide is $8.494 \%$ The difference in weight is $4.335 \mathrm{~g}$ representing the dissolved polymer representing $16.58 \%$ and the total will be $25.5 \%$. It means that the percentage of dissolved substance in nitric acid is $74.50 \%$.

FESEM results of copper nanoparticles using hydrazine hydrate: It was observed that $7 \mathrm{ml}$ of hydrazine hydrate reduces copper ions and causes precipitation of copper from $1 \mathrm{M}$ copper sulfate solution, $0.7 \mathrm{ml}$ for the second concentration and 0.07 for the third one. The weight of the residue 
from the previous solution after filtration and drying as follows: for $1 \mathrm{M}$ solution $2.0193 \mathrm{~g}$, for $0.01 \mathrm{M} 0.107 \mathrm{~g}$ and for $0.01 \mathrm{M} 0.0337 \mathrm{~g}$. Fig. (2), (3) and (4) showed copper nanoparticles by FESEM.

It was observed that the size of the nanoparticles of copper was changed by changing the concentration of the solution. With the same solvent. The sizes of the nanoparticles with different concentrations of $\mathrm{CuSO}_{4}$ are shown in Table (4).

Table(4): Copper nanoparticles size using hydrazine hydrate.

\begin{tabular}{|c|c|c|}
\hline Concentration of CuSO & Size range $/ \mathbf{n m}$ & Magnification \\
\hline \hline $1 \mathrm{M}$ & $162.9-305.8$ & $15000 \mathrm{x}$ \\
\hline \multirow{3}{*}{$0.1 \mathrm{M}$} & $244.6-924.8$ & $15000 \mathrm{x}$ \\
\cline { 2 - 3 } & $44.97-470.7$ & $30000 \mathrm{x}$ \\
\cline { 2 - 3 } & $32.74-324.8$ & $60000 \mathrm{x}$ \\
\hline $0.01 \mathrm{M}$ & $73.2-304.8$ & $60000 \mathrm{x}$ \\
\hline
\end{tabular}



Fig. (2): Copper nanoparticles from $1 \mathrm{M} \mathrm{CuSO}_{4}$ and hydrazine hydrate at $15000 \mathrm{x}$ 


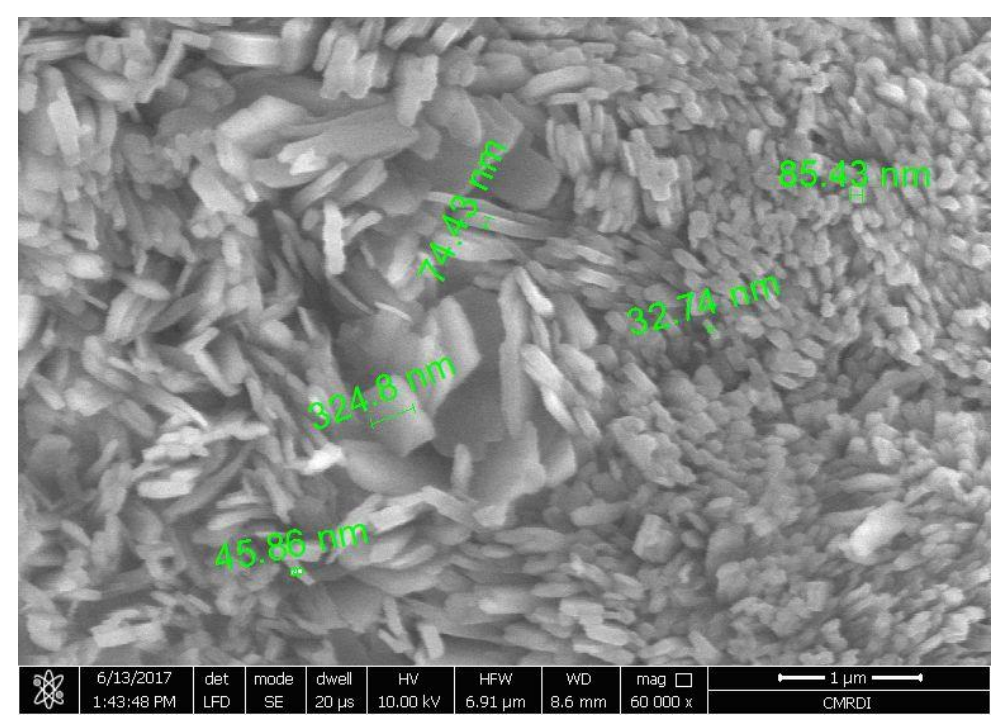

Fig. (3): Copper nanoparticles from $0.1 \mathrm{M} \mathrm{CuSO}_{4}$ and hydrazine hydrate at $60000 \mathrm{x}$

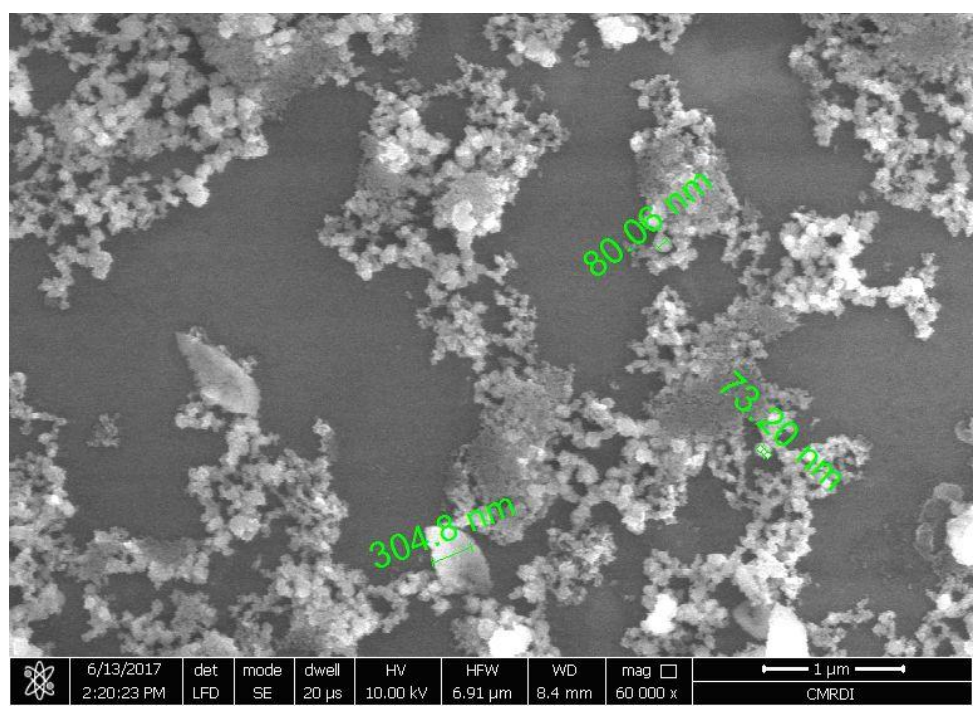

Fig. (4): Copper particles from $0.01 \mathrm{M} \mathrm{CuSO}_{4}$ and hydrazine hydrate at 60 $000 \mathrm{x}$ 
It was observed that the $0.01 \mathrm{M}$ copper (II) sulfate concentration has produced the smaller size of copper nanoparticles with hydrazine hydrate.

The results of addition of ascorbic acid, hydrazine hydrate and the mixture of both 1:1 in ratio to copper (II) sulfate on CCG substrate are shown in Tables (5) and (6).

Table (5): Volume of ascorbic acid, hydrazine hydrate and mixture of them needed to reduce copper ions

\begin{tabular}{|l|c|c|c|}
\hline \multicolumn{1}{|c|}{ Grade } & $\begin{array}{c}\text { Volume of } \\
\text { ascorbic } \\
\text { acid/ml }\end{array}$ & $\begin{array}{c}\text { Volume of } \\
\text { hydrazine } \\
\text { hydrate/ml }\end{array}$ & $\begin{array}{c}\text { Volume of the } \\
\text { hydrazine hydrate } \\
\text { and ascorbic acid/ml }\end{array}$ \\
\hline $\begin{array}{l}\text { Less than 0.9 } \\
\text { mm }\end{array}$ & 44.7 & 5.4 & 15.6 \\
\hline $\begin{array}{l}\text { More than 0.9 } \\
\text { mm and less } \\
\text { than 2 mm }\end{array}$ & 38 & 4.11 & 9 \\
\hline $\begin{array}{l}\text { more than 2 } \\
\text { mm }\end{array}$ & 32.7 & 3 & 7.9 \\
\hline
\end{tabular}

It was observed from Table (5) that the volumes of the reagents are decreased with the increase in the grade of the CCG. Ascorbic acid has the greatest volume consumed while hydrazine hydrate shows the least volume.

Table (6) showed that the weight of nanoparticles is increased by increasing the size of CCG in case of ascorbic acid and hydrazine hydrate while there is a decrease in case of the mixture of both. Also for the same size we found that the weight was small using ascorbic acid, but increases by using hydrazine hydrate and becomes larger using the mixture. 
Khalil, et al

Table (6): Weight of copper nanoparticles treated with hydrazine hydrate, ascorbic acid and mixture of them.

\begin{tabular}{|l|c|c|c|}
\hline \multirow{2}{*}{ Grade of CCG } & \multicolumn{3}{|c|}{$\begin{array}{c}\text { Weight of copper nanoparticles/g using } \\
\text { different reducing agents }\end{array}$} \\
\cline { 2 - 4 } & $\begin{array}{c}\text { Ascorbic } \\
\text { acid }\end{array}$ & $\begin{array}{c}\text { Hydrazine } \\
\text { hydrate }\end{array}$ & $\begin{array}{c}\text { Mixture of hydrazine } \\
\text { hydrate \& ascorbic acid }\end{array}$ \\
\hline Less than $0.9 \mathrm{~mm}$ & $0.70 \mathrm{~g}$ & $1.91 \mathrm{~g}$ & $2.91 \mathrm{~g}$ \\
\hline $\begin{array}{l}\text { More than } 0.9 \mathrm{~mm} \text { and } \\
\text { less than } 2 \mathrm{~mm}\end{array}$ & $1.04 \mathrm{~g}$ & $2.18 \mathrm{~g}$ & 2.82 \\
\hline more than $2 \mathrm{~mm}$ & $1.48 \mathrm{~g}$ & $2.57 \mathrm{~g}$ & $2.65 \mathrm{~g}$ \\
\hline
\end{tabular}

Table (7) showed the different sizes of copper nanoparticles with the different grades of the CCG. For grade $<0.9 \mathrm{~nm}$ using ascorbic acid the size of copper nanoparticles obtained have the size range between 26.22 and 68.64 $\mathrm{nm}$ as shown in Fig. (5) and between 32.74 and $68.04 \mathrm{~nm}$ at grade $>2 \mathrm{~mm}$ (Fig. 6). For hydrazine hydrate, the range was between 44.97 and $135.6 \mathrm{~nm}$ with grade $<2 \mathrm{~mm}$ (Fig. 7) and for the mixture it was between 35.12 and $89.93 \mathrm{~nm}$ with grade $>2 \mathrm{~mm}$ (Fig. 8). Mustafa and İlkay (2010) discussed that the size of copper nanoparticles are decreased with increasing the molar ratio of ascorbic acid to copper (II) sulfate of the range between 90 and 250 $\mathrm{nm}$. 
Table (7) : The size of copper nanoparticles by different reducing agents and CCG grades.

\begin{tabular}{||c|c|c|c|}
\hline \multirow{2}{*}{$\begin{array}{c}\text { Grade of } \\
\text { CCG/mm }\end{array}$} & \multicolumn{3}{|c|}{ Size of copper nanoparticles /nm at $60000 \mathrm{x}$} \\
\cline { 2 - 4 } & Ascorbic acid & $\begin{array}{c}\text { Hydrazine } \\
\text { hydrate }\end{array}$ & $\begin{array}{c}\text { Mixture of ascorbic acid } \\
\text { and hydrazine hydrate }\end{array}$ \\
\hline \hline$<0.9$ & $26.22-68.64$ & $81.06-162.1$ & $\begin{array}{c}151.2-279.5 \\
214.9-403.8\end{array}$ \\
\hline$<2$ & $109.8-400.9$ & $44.97-135.6$ & $310.4-611.5$ \\
\hline & $32.74-68.04$ & & $35.12-89.93$ \\
& $57.58-121.0$ & $35.12-669.7$ & $125.3-354.4$ \\
& $108.1-297.1$ & & $76.57-658.4$ \\
\hline
\end{tabular}

It was observed that with ascorbic acid the nanoparticles were clear without formation of sticky or gum like substances as in case of hydrazine hydrate or the mixture which is the worst one. Using ascorbic acid makes filtration of the nanoparticles much easier than the other two reagents.

Chen and Lim (2002) found out that hydrazine hydrate was found to be an effective reducing agent for the recovery of copper. Among various factors, the solution $\mathrm{pH}$ was the most important. The optimum reduction of these metals can be achieved at $\mathrm{pH}>11$. 
Khalil, et al



Fig. (5): Copper nanoparticles on CCG of grade $<0.9$ using ascorbic acid.

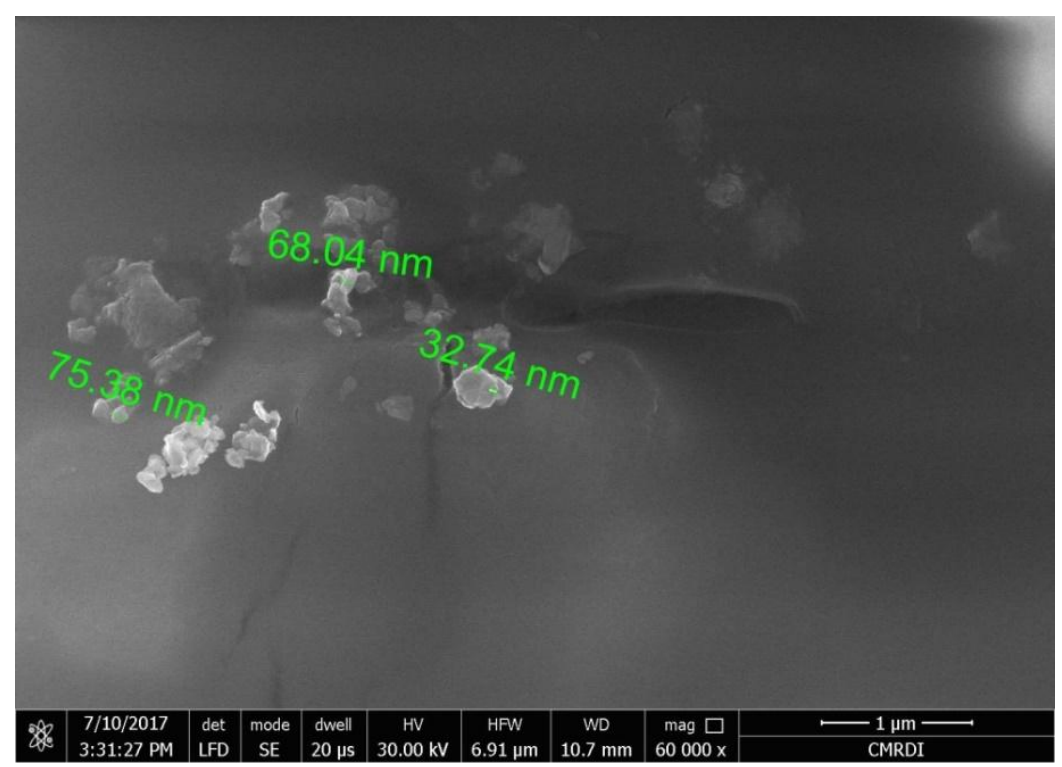

Fig. (6): Copper nanoparticles on CCG of grade $>2 \mathrm{~mm}$ using ascorbic acid.

Vol. 40, No.1, Dec. 2017 


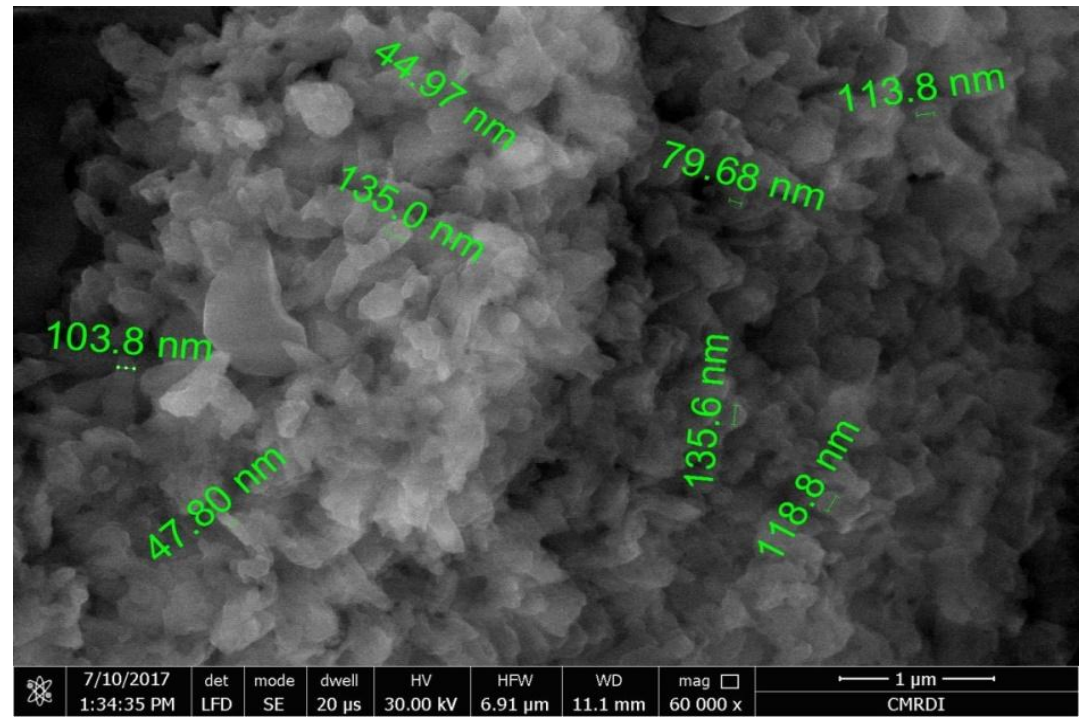

Fig.(7): Copper nanoparticles on CCG of grade $<2 \mathrm{~mm}$ using hydrazine hydrate.



Fig. (8): Copper nanoparticles on CCG of grade > $2 \mathrm{~mm}$ using mixture of ascorbic acid and hydrazine hydrate 1:1 in ratio. 
From the values obtained, the optimum conditions to obtain the suitable nanoparticle size of copper $<100 \mathrm{~nm}$ is using ascorbic acid as a reducing agent with the grade of $\mathrm{CCG}<0.9 \mathrm{~nm}$. Also with grade $>2 \mathrm{~mm}$ It has a good result as the size obtained is ranged between 32.74 and $68.04 \mathrm{~nm}$.

\section{CONCLUSION}

Copper nanoparticles have been prepared using hydrometallurgical process of PCBs in ammonia solution. The percentage of copper $8.928 \%$. Reducing agents were used to prepare copper nanoparticles on the CCG substrate yielding different sizes of copper depending upon the reducing agent, the grade of the substrate. Ascorbic acid produced size of copper nanoparticles $<100 \mathrm{~nm}$ with CCG grade $<0.9 \mathrm{~mm}$.

\section{REFERENCES}

Afroz, R.; Masud, M.M.; Akhtar, R. and Duasa, J.B. (2013): Survey and analysis of public knowledge, awareness and willingness to pay in Kuala Lumpur, Malaysia - a case study on household WEEE management. J. Clean. Prod., 52, 185-193.

Chen, J.P and Lim, L.L.(2002): Key factors in chemical reduction by hydrazine for recovery of precious metals. Chemosphere 49:363370 .

Cheng X.; Zhang X.; Yin H.; Wang A. and Xu Y. (2006): Modifier effects on chemical reduction synthesis of nanostructured copper. Appl. Surf. Sci., 253, 2727.

Cui, J. and Zhang, L. (2008): Metallurgical recovery of metals from electronic waste: a review. Journal of Hazardous Materials, 158: $228-256$. 
European Parliament.( 2003): Directive 2002/96/EC of the European Parliament and of the Council of 27 January 2003 on waste electrical and electronic equipment (WEEE). Off. J. Eur. Union, L37, 24-38.

Flandinet, L.; Tedjar, F.; Ghetta, V.and Fouletier, J. (2012): Metals recovering from waste printed circuit boards (WPCBs) using molten salts. J. Hazard. Mater. 213, 485-490.

Goosey, M. and Kellner, R. (2003): Recycling technologies for the treatment of end of life printed circuit boards (PCBs). Circuit World 29, 33 37.

Hagelüken, C. (2006): Improving Metal Returns and Eco-Efficiency in Electronics Recycling-A Holistic Approach for Interface Optimisation between Pre-Processing and Integrated Metals Smelting and Refining. In Proceedings of the IEEE International Symposium on Electronics and the Environment, Scottsdale, AZ, USA pp. 8-11.

Marques, A.C.; Cabrera, J.M.; Malfatti, C.D.F. (2013): Printed circuit boards: a review on the perspective of sustainability. J. Environ. Manag., $131,298-306$.

Mustafa B. and, İlkay Ş. (2010): Controlled synthesis of copper nano/ microstructures using ascorbic acid in aqueous CTAB solution. Powder Technology 198, 279-284.

Noon, M.S., Lee, S.J., Cooper, J.S., (2011): A life cycle assessment of endof-life computer monitor management in the Seattle metropolitan region. Resour. Conserv. Recycl. 57, 22-29.

Oh, C.J.; Lee, S.O.; Yang, H.S.; Ha, T.J.; Kim, M.J. (2003): Selective leaching of valuable metals from waste printed circuit boards. Air Waste Manage. Assoc., 53, 897-902.

Robinson, B.H. (2009): E-waste: An assessment of global production and environmental impacts. Sci. Total Environ., 408, 183-191.

Sinha, A.n and Sharma, B.P. (2002): Preparation of copper powder by glycerol process. Mater. Res. Bull. 37, 407. 
Thi, M.; Thi, T.; Eric, F. and Mau, C. (2011): Synthesis and optical properties of copper nanoparticles prepared by a chemical reduction method Adv. Nat. Sci.: Nanosci. Nanotechnol. 2, 015009 (6pp).

Yang, H.; Liu, J.; Yang, J. (2011): Leaching copper from shredded particles of waste printed circuit boards. J. Hazard. Mater., 187, 393-400.

Yang, X.; Sun, L.; Xiang, J.; Song, H. and Sheng, S. ( 2013): Pyrolysis and dehalogenation of plastics from waste electrical and electronic quipment (WEEE): a review. Waste Management, 33, (2), pp.462-473.

Zhang Q.; Yang Z. ; Ding B.; Lan X.; Guo Y. (2010): Preparation of copper nanoparticles by chemical reduction method using potassium borohydride. Trans. Nonferrous met. Soc. China 20: 240-244.

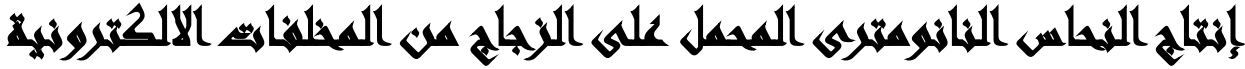

[1]

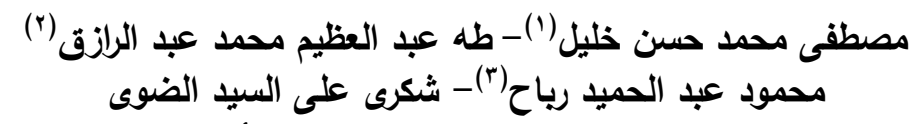

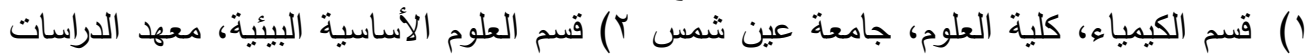

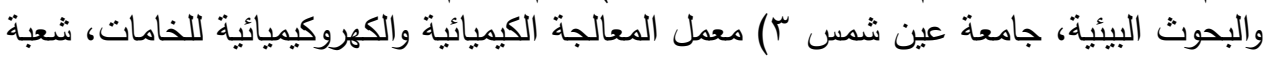

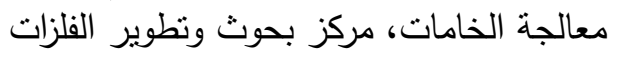

\section{المستخلس}

يزداد معدل المخلفات الالكترونية من ب-ه \% سنويا مما بشكل عبئًا ثقيلا على النظام البيئى



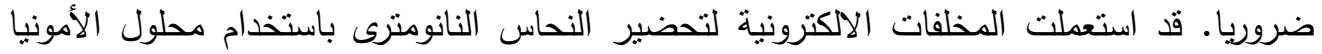

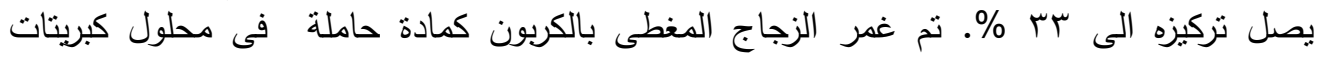
النحاس (II) الذى نم تحضيره باضافة حمض الكبرئن الكيك الى المحلول. اختزلت ايونات النحاس بواسطة

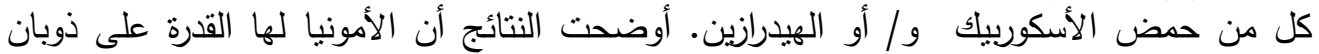






J. Environ. Sci.

Institute of Environmental Studies and Research - Ain Shams University

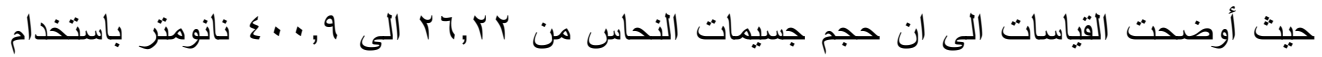

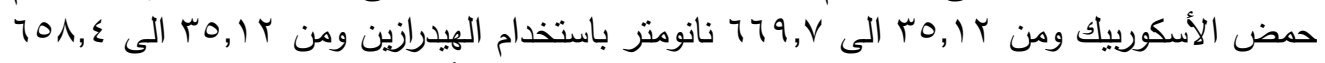
نانومتر باستخدام خليط منهما بنسبة ا:ا الـ وقد ثثبت من الدراسة أن عملية التحضير سهلة وبسيطة واقتصادية. 